\title{
DEVELOPMENT OF THE FORMULATION OF A NEW KIND OF CHOCOLATE BROWNIE FOR SPECIAL PURPOSE
}

\author{
I. Ditrikh, N. Yevtushenko \\ National University of Food Technologies
}

\begin{tabular}{l}
$\quad$ Key words: \\
Celiac disease \\
Agglutinin flour \\
Chocolate brownie for \\
special purpose \\
Organoleptic and \\
physico-cemical \\
indicators \\
Nutritional value \\
Integral accelerator \\
\hline
\end{tabular}

Article history:

Received 10.01.2018

Received in revised form

30.01.2018

Accepted 07.02.2018

Corresponding author:

I. Ditrikh

E-mail:

npnuht@ukr.net

\begin{abstract}
The present dictates important questions about the possibility of combining quality health nutrition in the restaurant industry. The perspective issue is the technology and the production of special purpose products aimed for the prevention and treatment of alimentary-dependent diseases. These types of products include, first of all glutenfree products.

It is analyzed that flour confectionery products are very popular under the conditions of the restaurants' facilities, the prescription composition of most of them contains components that are "poison" for people with intolerance to gluten.

The peculiarities of the formation of the food ration of people with celiac disease are considered. The analysis of the manifestations of the disease on the gluten enteropathy was carried out and the possibility of its treatment with the help of a baguette diet was determined. The necessity of making agglutinin products of native production is substantiated. The perspective directions of creation of confectionery products for patients with celiac disease and the elderly people are determined. The chemical composition, biological and nutritional value of agglutinin flour were analyzed, its physical and chemical parameters are determined. The possibility of complete replacement of wheat flour on agglutinin and rice has been established.

The recipe of a new type of chocolate brownies for special purpose using agglutinin flour has been developed and scientifically substantiated. The quality of the product is evaluated according to organoleptic parameters. The current normative document defines the physical and chemical quality indicators that are within the limits of regulated values. The nutritional value is calculated according to the integral accelerator. According to the norms of physiological needs, the degree of provision of the human body in the nutrients is determined by the consumption of a new type of chocolate brownie "Fantasy" of special purpose.
\end{abstract}

DOI: $10.24263 / 2225-2924-2018-24-1-26$ 


\title{
РОЗРОБКА РЕЦЕПТУРИ НОВОГО ВИДУ ШОКОЛАДНОГО БРАУНІ СПЕЦІАЛЬНОГО ПРИЗНАЧЕННЯ
}

\author{
І.В. Дітріх, Н.В. Свтушенко \\ Національний університет харчових технологій
}

Поєднання якісного оздоровчого харчування в умовах закладів ресторанного господарства є важливим завданням сьогодення. Перспективним питанням залишається технологія та виробництво продуктів спеціального призначення, спрямованих на профілактику та лікування аліментарно-залежних захворювань. До таких видів продуктів можна віднести передусім аглютенові вироби.

Великою популярністю в умовах реалій закладів ресторанного господарства користуються борошняні кондитерські вироби, рецептурний склад більшості з яких містить компоненти, що є “отрутою” для людей з непереносимістю глютену.

У статті розглянуто особливості формування харчового раціону людей, хворих на целіакію. Проведено аналіз проявів захворювання на глютенову ентеропатію та визначено можливість його лікування за допомогою аглютенової дієти. Обтрунтовано необхідність виготовлення аглютенових виробів вітчизняного виробництва. Визначено перспективні напрямки створення кондитерських виробів для хворих на иеліакію та людей похилого віку. Проаналізовано хімічний склад, біологічну та харчову иінність аглютенового борошна, його фізико-хімічні показники. Встановлено можливість повної заміни пшеничного борошна на аглютенове пшоняне та рисове.

Розроблено і науково обтрунтовано рецептуру нового виду шоколадного брауні спеціального призначення з використанням аглютенового борошна. Проведена оцінка якості виробу за органолептичними показниками. За чинним нормативним документом визначено фізико-хімічні показники якості, які знаходяться в межах регламентованих значень. Розраховано харчову цінність за інтегральним скором. За нормами фізіологічних потреб визначено ступінь забезпечення організму людини в нутрієнтах при споживанні нового виду шоколадного брауні «Фантазія» спеціального призначення.

Ключові слова: иеліакія, аглютенове борошно, шоколадний брауні спеціального призначення, органолептичні та фізико-хімічні показники, харчова иінність, інтегральний скор.

Постановка проблеми. Сучасне харчове виробництво - система, яка динамічно розвивається. Для задоволення попиту споживачів на продукцію спеціального призначення харчова промисловість орієнтується на інноваційні шляхи розвитку. За останні роки значно виросла кількість споживачів, які мінімізують або й взагалі відмовляються від надходження пшеничного борошна в раціон харчування. Тому сьогодні існує перспектива вдоскона- 
лення або розробка рецептур різних груп страв із заміною пшеничного борошна. Особливо це стосується борошняних кондитерських виробів, що $\epsilon$ популярними серед різних груп населення.

За оцінкою Всесвітньої асоціації гастроентерологів целіакією хворіє близько 1\% населення нашої планети [1]. Ця хвороба пов'язана з непереносимістю глютену (запасаючого білка), який містять злакові та продукти їх переробки. Симптоми глютенової ентеропатії можуть бути найрізноманітнішими - від характерної діареї, здуття живота і втрати ваги до анемії, слабкості, неврологічних порушень і сексуальних проблем.

Для хворих на целіакію в багатьох країнах розроблені технології аглютенового хліба, макаронних виробів, борошняних кондитерських виробів, борошна для випічки тощо. На жаль, в Україні виробництво аглютенових виробів не налагоджене. Асортимент продуктів цієї групи формується за рахунок зарубіжної продукції, яка має високу ціну, а вітчизняні підприємства харчової промисловості не виробляють аглютенові вироби, що обумовлено складністю технології [1]. У зв'язку з цим виникає необхідність розробки і впровадження якісних і доступних аглютенових борошняних виробів вітчизняного виробництва.

Аналіз останніх досліджень і публікацій. Створенню науково-практичних основ виробництва аглютенових харчових продуктів присвячені праці зарубіжних і вітчизняних вчених: E. Gallagher, E.K. Arendt, J.L. Casper, W.A. Atwell, E.J. Hoffenberg, J. Haas, M.M. Mor, J.T. Schober, E. K. Hattner, В.I. Дробот, А.М. Дорохович, О.М. Шаніної, О.В. Бабіч та ін [2 - 10]. У працях вчені приділяють особливу увагу хлібопекарській продукції, яка $\epsilon$ найбільш повсякденно вживаною і виступає головним джерелом глютену [11]. Однією з груп доступних аглютенових продуктів можуть бути кондитерські вироби вітчизняного виробництва, які користуються попитом і популярні у населення [12]. Основні результати досліджень останніх років дали могу суттєво розширити асортимент борошняних кондитерських виробів 3 використанням аглютенової сировини. В цю групу входять вафлі, кекси, мафіни, бісквіти, печиво, в рецептурі яких використовують аглютенове гречане, рисове, кукурудзяне борошно [13].

Вживання харчових продуктів, приготованих 3 аглютенової сировини, забезпечує не тільки лікування хворих на глютенову ентеропатію, але завдяки безглютеновій дієті і підтримку здорових людей на належному працездатному рівні [14]. Тому розробка і впровадження на вітчизняному ринку аглютенових виробів $є$ актуальним і своєчасним завданням.

Метою дослідження $є$ розробка рецептурного складу нового виду шоколадного брауні «Фантазія» спеціального призначення, обгрунтування його поживних властивостей, аналізу органолептичних і фізико-хімічних показників якості, визначення інтегрального скору.

Матеріали і методи. У дослідженні використані загальноприйняті методи органолептичних і фізико-хімічних досліджень, діалектичний метод наукового пізнання, методи теоретичного узагальнення, системного, структурного, компаративного, математичного аналізу, наукової індукції та дедукції, син- 
тезу, абстракції, праці зарубіжних і вітчизняних вчених, які стосуються проблем забезпечення аглютеновими продуктами окремих груп населення.

Виклад основних результатів дослідження. Як об'єкт досліджень було обрано борошняний кондитерський виріб - шоколадний брауні.

Брауні (англ. Chocolate brownie) — це шоколадний десерт у вигляді тістечка, торта, пирога або кексу з досить вологим м'якушем [15].

За класичною технологією для приготування шоколадного брауні використовують такі інгредіснти: какао-порошок (11...12\%), масло вершкове $(34 \ldots 35 \%)$, борошно пшеничне $(12 \%)$, цукор білий кристалічний $(24 . .25 \%)$, яйця курячі харчові (15-16\%) [16].

Запропоновано в рецептурі класичного брауні замінити борошно пшеничне на пшоняне та рисове. Така заміна дає змогу споживати страву хворим на глютенову ентеропатію та людям похилого віку. Це пояснюється тим, що білки пшоняного та рисового борошна не містять глютену (табл. 1).

\section{Таблиия 1. Показники якості пшеничного, пшоняного та рисового борошна}

\begin{tabular}{|c|c|c|c|}
\hline Найменування показника & $\begin{array}{c}\text { Борошно пшеничне, } \\
\text { в/c* }\end{array}$ & Борошно пшоняне** & Борошно рисове*** \\
\hline Зовнішній вигляд і колір & $\begin{array}{c}\text { Білий, білий із } \\
\text { жовтуватим } \\
\text { відтінком порошок }\end{array}$ & $\begin{array}{c}\text { Порошкоподібний } \\
\text { продукт світло- } \\
\text { жовтого кольору }\end{array}$ & $\begin{array}{c}\text { Порошок білого } \\
\text { кольору }\end{array}$ \\
\hline Запах і смак & $\begin{array}{c}\text { Властивий } \\
\text { пшеничному } \\
\text { борошну }\end{array}$ & $\begin{array}{c}\text { Притаманний } \\
\text { пшоняному борошну }\end{array}$ & Нейтральний \\
\hline Вміст клейковини, \% & 24 & Не містить & Не містить \\
\hline Масова частка вологи, \% & $\mathrm{He}>15$ & $\mathrm{He}>9$ & $\mathrm{He}>15$ \\
\hline Кислотність, град. & $\mathrm{He}>3,5$ & $\mathrm{He}>6$ & $\mathrm{He}>2,5$ \\
\hline
\end{tabular}

* - ДСТУ 46.004-99.

** - ТУ 9197-001-63528860-2010 (Росія).

*** — ТУ 15.6-00952737-006-2002.

Порівняльний аналіз хімічного складу пшеничного, пшоняного та рисового борошна представлено у табл. 2. Дані таблиці свідчать про те, що пшоняне та рисове борошно $є$ джерелами широкого спектра природних макро- та мікронутрієнтів.

Таблиця 2. Порівняльний хімічний склад пшеничного, пшоняного та рисового борошна [17]

\begin{tabular}{|c|c|c|c|}
\hline \multirow{2}{*}{ Харчові речовини } & \multicolumn{3}{|c|}{ Вміст у 100 г борошна } \\
\cline { 2 - 4 } & Пшеничне, в/с & Пшоняне & Рисове \\
\hline 1 & 2 & 3 & 4 \\
\hline Вода, г & 14,0 & 14,0 & 14,0 \\
\hline Білки, г & 10,3 & 11,5 & 7 \\
\hline Жири, г & 1,1 & 3,3 & 71,8 \\
\hline Вуглеводи, г & 69 & 67,2 & 70,7 \\
\hline в т. ч. крохмаль, г & 68,7 & 64,8 & 0,7 \\
\hline Зола & 0,5 & 1,3 & 12 \\
\hline \multicolumn{4}{|c|}{ Мінеральні речовини, мг $/ 100$ г } \\
\hline Na & 3 & 10 & 100 \\
\hline K & 122 & 211 & 1 \\
\hline
\end{tabular}


Продовження табл. 2

\begin{tabular}{|c|c|c|c|}
\hline 1 & 2 & 3 & 4 \\
\hline $\mathrm{Ca}$ & 18 & 27 & 8 \\
\hline $\mathrm{Mg}$ & 16 & 83 & 50 \\
\hline $\mathrm{P}$ & 86 & 233 & 150 \\
\hline $\mathrm{Fe}$ & 1,2 & 2,7 & 1,0 \\
\hline \multicolumn{2}{|c|}{ Вітаміни } \\
\hline Вітамін Е, мг & 2,57 & 2,6 & 0,45 \\
\hline Вітамін $\mathrm{B}_{6}, \mathrm{M \Gamma}$ & 0,17 & 0,52 & 0,18 \\
\hline Біотин, мкг & 2,0 & - & 3,5 \\
\hline Ніацин, мг & 1,2 & 1,55 & 1,6 \\
\hline Пантотенова кислота, мкг & 0,3 & - & 0,4 \\
\hline Рибофлавін, мг & 0,04 & 0,04 & 0,04 \\
\hline Тіамін, мг & 0,17 & 0,42 & 0,08 \\
\hline Фолацин, мкг & 27,1 & 40,0 & 19,0 \\
\hline Холін, мг & 52,0 & - & 78,0 \\
\hline Енергетична цінність, кДж & 1372,35 & 1443,5 & 1359,8 \\
\hline
\end{tabular}

Висока біологічна цінність білків таких видів борошна обумовлена вмістом незамінних амінокислот.

Білки рисового борошна, так само як і пшеничного, лімітовані за лізином i треоніном. Скор амінокислот білків рисового борошна вищий і становить за лізином - 68\%, за треоніном - 86\%, тоді як пшеничного,відповідно, 44\% і $76 \%$. Білки пшоняного борошна лімітовані за лізином - 46\% та валіном 80\% Домінуючими є ізолейцин, лейцин, триптофан (табл. 3).

Таблиця 3. Амінокислотний склад білків борошна мг/100 г борошна [17]

\begin{tabular}{|c|c|c|c|c|c|c|c|}
\hline Амінокислота & $\begin{array}{c}\text { Шкала } \\
\text { FAO }\end{array}$ & $\begin{array}{c}\text { Пшенич- } \\
\text { не, в/с }\end{array}$ & Скор, \% & Пшоняне & Скор, \% & Рисове & Скор, \% \\
\hline \multicolumn{8}{|c|}{ Незамінні амінокислоти } \\
\hline Валін & 5,0 & 470 & 91 & 470 & 80 & 420 & 120 \\
\hline Ізолейцин & 4,0 & 430 & 104 & 430 & 94 & 330 & 117 \\
\hline Лейцин & 7,0 & 806 & 112 & 1534 & 190 & 620 & 127 \\
\hline Лізин & 5,5 & 250 & 44 & 288 & 46 & 260 & 68 \\
\hline Треонін & 4,0 & 311 & 76 & 400 & 87 & 240 & 86 \\
\hline Триптофан & 1,0 & 100 & 97 & 180 & 157 & 100 & 143 \\
\hline Фенілаланін & 6,0 & 500 & 80 & 580 & 84 & 370 & 88 \\
\hline \multicolumn{8}{|c|}{ Замінні амінокислоти } \\
\hline Аланін & & 330 & & 1075 & & 390 & \\
\hline Аргінін & & 400 & & 425 & & 510 & \\
\hline Аспарагінова кислота & & 340 & & 650 & & 540 & \\
\hline Гістидин & & 200 & & 260 & & 170 & \\
\hline Гліцин & & 350 & & 300 & & 320 & \\
\hline Глутамінова кислота & & 3080 & & 2220 & & 1200 & \\
\hline Пролін & & 970 & & 810 & & 330 & \\
\hline Серин & & 500 & & 700 & & 330 & \\
\hline Тирозин & & 250 & & 410 & & 290 & \\
\hline Цистеїн & & 200 & & 180 & & 137 & \\
\hline
\end{tabular}

Пшоняне борошно сприяє покращенню травлення, виведенню з організму токсинів і баластних речовин. Рисове борошно є добрим згущувачем, володіє високою здатністю до набрякання [18]. 
Запропоновано повну заміну пшеничного борошна у класичній рецептурі шоколадного брауні на суміш аглютенового у такому співвідношенні 70:30 (пшоняне борошно:рисове борошно). Така рецептура страви дає змогу отримати гармонійні органолептичні показники якості (табл. 4).

Таблиця 4. Органолептичні показники якості шоколадного брауні (контрольного зразку) та шоколадного брауні «Фантазія» спеціального призначення

\begin{tabular}{|c|c|c|}
\hline \multirow{2}{*}{$\begin{array}{c}\text { Найменування } \\
\text { показника }\end{array}$} & \multicolumn{2}{|c|}{ Характеристика } \\
\hline & Шоколадний брауні, контроль & Шоколадний брауні «Фантазія» \\
\hline Форма & $\begin{array}{c}\text { Правильна, що відповідає формі, } \\
\text { встановленій за рецептурою }\end{array}$ & $\begin{array}{c}\text { Правильна, що відповідає формі, } \\
\text { встановленій за рецептурою }\end{array}$ \\
\hline Поверхня & $\begin{array}{c}\text { Рівна, без розломів, що свідчить } \\
\text { про правильний вибір темпе- } \\
\text { ратури, при якій випікали брауні, } \\
\text { не підгоріла. Злегка блискуча }\end{array}$ & $\begin{array}{c}\text { Рівна, без розломів, що свідчить } \\
\text { про правильний вибір температури, } \\
\text { при якій випікали брауні; не } \\
\text { підгоріла } \\
\end{array}$ \\
\hline Колір & $\begin{array}{c}\text { Від світло-коричневого до } \\
\text { коричневого, відповідає } \\
\text { складовим рецептури } \\
\end{array}$ & $\begin{array}{c}\text { Коричневий, що свідчить про } \\
\text { використання какао темного }\end{array}$ \\
\hline Консистенція & $\begin{array}{c}\text { Достатньо м'яка, однорідна, без } \\
\text { слідів непромісу }\end{array}$ & $\begin{array}{c}\text { Достатньо м'яка, однорідна, без } \\
\text { слідів непромісу }\end{array}$ \\
\hline Смак і запах & $\begin{array}{c}\text { Смак шоколаду, запах какао. Без } \\
\text { стороннього запаху. }\end{array}$ & $\begin{array}{c}\text { Смак шоколаду, запах какао. Без } \\
\text { стороннього запаху }\end{array}$ \\
\hline
\end{tabular}

Фізико-хімічні показники визначили стандартними методами контролювання (табл. 5).

У зв'язку з тим, що в Україні відсутні нормативно-технічні документи на рецептуру шоколадного брауні, отримані результати фізико-хімічних досліджень зразків брауні «Фантазія» порівняли з показниками для класичного брауні, рецептуру якого умовно можна віднести до виробів, що виготовляють за ДСТУ 4505:2005 [19].

Таблиия 5. Фізико-хімічні показники якості шоколадного брауні (контрольного зразка) та шоколадного брауні «Фантазія» спеціального призначення

\begin{tabular}{|c|c|c|c|c|}
\hline $\begin{array}{c}\text { Найменування } \\
\text { показника }\end{array}$ & $\begin{array}{c}\text { Вимоги } \\
\text { ДСТУ } \\
4505: 2005\end{array}$ & $\begin{array}{c}\text { Зразок } \\
\text { шоколадного } \\
\text { брауні, контроль }\end{array}$ & $\begin{array}{c}\text { Зразок } \\
\text { шоколадного } \\
\text { брауні «Фантазія» }\end{array}$ & $\begin{array}{c}\text { Метод } \\
\text { контролювання }\end{array}$ \\
\hline $\begin{array}{c}\text { Масова частка } \\
\text { вологи, \% }\end{array}$ & $16,0 \ldots 23,0$ & 19,9 & 20,5 & ГОСТ 5900 \\
\hline $\begin{array}{c}\text { Масова частка жиру } \\
\text { в перерахунку на } \\
\text { суху речовину,\% }\end{array}$ & $2,2 \ldots 34,2$ & 32,7 & 32,9 & ГОСТ 5904 \\
\hline $\begin{array}{c}\text { Масова частка загаль- } \\
\text { ного цукру (за сахаро- } \\
\text { зою) \%, в перерахун- } \\
\text { ку на суху речовину }\end{array}$ & $16,0 \ldots 60,8$ & 24,6 & 24,6 & ГОСТ 5903 \\
\hline Лужність, град & $2,0 \ldots 3,0$ & 2,4 & 2,4 & ДСТУ 5024:2008 \\
\hline
\end{tabular}

За результатами досліджень встановлено, що введення у рецептуру шоколадного брауні спеціального призначення аглютенової сировини дає змогу отримати страву 3 високими органолептичними та відповідними фізикохімічними показниками якості. 
Харчову цінність шоколадного барауні «Фантазія» визначили методом інтегрального скору за рекомендаціями А.А. Покровського [20]. Отримані результати представлено у табл. 6 .

Табличя 6. Інтегральний скор шоколадного брауні «Фантазія»

\begin{tabular}{|c|c|c|c|}
\hline Харчові речовини & $\begin{array}{c}\text { Добова потреба } \\
\text { у харчових речовинах, г } *\end{array}$ & $\begin{array}{c}\text { Вміст харчових речовин } \\
\text { у } 100 \text { г брауні ** }\end{array}$ & $\begin{array}{l}\text { Інтегральний } \\
\text { скор, \% }\end{array}$ \\
\hline Білки, г & 61 & 6,3 & \\
\hline Ліпіди, г & 62 & 29,6 & 47,7 \\
\hline Вуглеводи, г & 352 & 36,8 & 10,5 \\
\hline Кальцій, мг & 1100 & 26,4 & 2,6 \\
\hline Фосфор, мг & 1200 & 142,8 & 11,9 \\
\hline Магній, мг & 350 & 28,44 & 8,1 \\
\hline Залізо, мг & 17 & 2,56 & 15,1 \\
\hline Вітамін А, мг & 1 & 0,33 & 33 \\
\hline Вітамін $\mathrm{B}_{1}$, мг & 1,3 & 0,055 & 4,2 \\
\hline Вітамін $\mathrm{B}_{2}, \mathrm{M \Gamma}$ & 1,6 & 0,155 & 9,7 \\
\hline Вітамін РР, мг & 16 & 0,3 & 1,9 \\
\hline
\end{tabular}

*_[ [21].

$* *$ - [17].

За даними табл. 6 встановлено, що добова потреба в білках за рахунок споживання 100 г шоколадного брауні «Фантазія» забезпечується на 10,3\%, в жирах - на $47,7 \%$, вуглеводах - на $10,5 \%$. Ступінь забезпечення у мінеральних речовинах становить $2,6 \ldots 15,1 \%$, у вітамінах $-1,9 \ldots 33 \%$.

Відповідно до норм фізіологічних потреб (як приклад, взяли показники для жінок віком 18-29 років, 2-ї групи інтенсивності праці, які можуть хворіти на целіакію) добова потреба в енергії становить 2200 ккал або 9 204,8 кДж [21]. Встановлено, що 100 г шоколадного брауні «Фантазія» може задовольнити близько $20 \%$ добової потреби енергетичних затрат.

\section{Висновки}

Доведено доцільність використання в класичній рецептурі шоколадного брауні аглютенового борошна, що дає змогу розширити асортимент цієї групи страв для хворих на целіакію та для людей похилого віку. Розроблена рецептура шоколадного брауні «Фантазія» спеціального призначення, у складі якої використовується пшоняне та рисове борошно у співвідношенні 70:30 відповідно. Визначено органолептичні властивості, які свідчать про високу якість виробу. Наведено результати фізико-хімічних досліджень брауні «Фантазія», які знаходяться в межах нормативних значень за показниками, що регламентуються. Розраховано інтегральний скор нового виробу.

У подальших дослідженнях буде проведено адаптацію рецептури шоколадного брауні для хворих на цукровий діабет.

\section{Література}

1. Дорохович В.В. Безглютенові борошняні кондитерські вироби / В.В. Дорохович, Н.П. Лазоренко // Обладнання та технології харчових виробництв. - 2013. - Вип.30.- С. 341-347.

2. Gallagher E. Recent advances in the formulation of gluten-free cereal-based products / E.Gallagher,T.R. Gormley, E.K. Arendt // Trends in Food Science \& Technology. — 2003. Vol. 15. - P. 143-152. 
3. Arendt E.K. Development of gluten-free cereal products / E.K.Arendt, C.M.O' Brien, T.J. Schober, E. Gallagher, T.R. Gormley // Farm \& Food. — 2002. — P. 21-27.

4. Hoffenberg E.J. Atrial of oats in children with newly diagnosed celiac disease / E.J. Hoffenberg, J. Haas, A. Drescher, R. Barnhurst, I. Osberg, F. Bao, G. Eisenbarth // J. Pediatr. - 2000. - Vol. 137. - P. 361-366.

5. Mor M.M. Network formation in gluten-free bread with application of transglutaminase / M.M. Mor, M. Heinbockel, P. Dockery, H.M. Ulmer, E.K. Arendt // Cereal Chem. — 2006. Vol. $83-$ P. $18-36$.

6. Schober J.T. Gluten-free bread from sorghum: quality differences among hybrids / J.T. Schober, M. Messerschmidt, S.R. Bean, S.H. Park, E.K. Arendt // Cereal Chemistry. 2004. - Vol. 82. - P. $394-404$.

7. Hattner E.K. Rheological properties and bread making performance of commercial wholegrain oat flour / E.K. Hattner, F. Dal Bello, E.K. Arendt // Journal of Cereal Science. 2010. - Vol. 52. - P. 65-71.

8. Дробот B.I. Технологічні аспекти використання борошна круп'яних культур у технології безглютенового хліба / В.І. Дробот, А.М. Грищенко // Обладнання та технології харчових виробництв: темат. зб. наук. пр. / Донец. нац. ун-т економіки і торгівлі ім. М. Туган- Барановського. - 2013. - Вип. 30. - С. 52-58.

9. Дорохович А.M. Мафіни на безглютеновому борошні для хворих на целіакію / А.М. Дорохович, Н.П. Лазоренко // Ukrainian Food Journal. — 2012. — № 1. — С. 61-58.

10. Бабіч O.B. Розроблення технології безглютенового печива для хворих на целіакію : автореф. дис. ...канд.техн.наук.: 05.18 .01 / О.В. Бабіч.; Нац. ун-т харч. технологій. Київ, 2006. - 20 c.

11. Лобачова Н.Л. Удосконалення технології безглютенових хлібобулочних виробів : монографія / Н. Л. Лобачова. - Суми : Сумський національний аграрний університет, 2015. - 214 с.

12. Бабіч O.B. Проблематика забезпечення спеціалізованими продуктами харчування хворих на целіакію в Україні / О.В. Бабіч, М.М. Віхоть // Проблемы старения и долголетия. - 2016. - Т. 25, № 2.- С. 230-234.

13. Шаніна O.M. Вплив технологічних факторів на супінь пенетрації хлібобулочних виробів спеціального призначення / О.М. Шаніна, Е.В. Жуков, А.В. Нурєєва // Технологичский аудит и резервы производства. - 2016. - № 2(4).- С. 30-35.

14. Ярославцева E. Непереносимость глютена / Е. Ярославцева // Хлібопекарська i кондитерська промисловість України. - 2011. - № 1. - С. 36-37.

15. McCarthy E. Who Invented the Brownie? / Е. McCarthy// MentalFloss. - 2014 [Електронний ресурс]. - Режим доступу : http://mentalfloss.com/article/60011/who-invented-brownie.

16. Матиящук O.B. Удосконалення рецептури шоколадних тістечок «Брауні», збагачених льняним та вівсяним борошном [Текст] / О. В. Матиящук, Н. В. Башкірова // Молодий вчений. — 2017. - № 2. - С. 192-196.

17. Химический состав пищевых продуктов: справочные таблицы содержания основных пищевых веществ и энергетической ценности пищевых продуктов / под. ред. проф., д-ра техн. наук и. М. Скурихина, проф., д-ра мед. наук М.Н. Волгарева. — 2-е изд., перераб. и доп. - Москва : ВО «Агропромиздат», 1987. — 224 с.

18. Дудкіна О.О. Формування показників якості фонданів спеціального призначення / О.О. Дудкіна, А.В. Гавриш, О.В. Нєміріч // Якість і безпека харчових продуктів : матеріали II міжнар. науково-практичної конференції, 12-13 листопада, 2015. - С. 118-121.

19. Кекси. Загальні технічні умови: ДСТУ4505:2005. - [Чинний від 2006-10-01]. Київ : Держспоживстандарт України, 2006.-18 с.

20. Технологія та лабораторний практикум кондитерських виробів і харчових концентратів : навч. посіб. / за ред. Проф. А.М. Дорохович і проф. В.М. Ковбаси. - Київ :Фірма «НКОС», 2015. - С. 36-41.

21. Про затвердження Норм фізіологічних потреб населення України в основних харчових речовинах та енергії (наказ від 18.11.1999 № 272). - Режим доступу : zakon.rada.gov.ua/laws/show/z0834-99. 